ISSN : $2302-1590$

E-ISSN: $2460-190 \mathrm{X}$

ECONOMICA

Journal of Economic and Economic Education Vol.4 No.2 (233-239)

\title{
PENGARUH FAKTOR LINGKUNGAN KERJA DAN FAKTOR INDIVIDU TERHADAP PRESTASI KERJA KARYAWAN PADA PT.POS INDONESIA (Persero) KANTOR AREA II PADANG
}

\author{
Rizky Natassia, Vivi Indria \\ Program Studi Pendidikan Ekonomi STKIP- PGRI Sumbar \\ Jl. Gunung Pangilun No.1, Padang Sumatera Barat \\ Email : Rizkynatassia@gmail.com \\ submited:2015.12.02 reviewed:2016.07.01 accepted: 2016.07.01 \\ http://dx.doi.org/10.22202/economica.2016.v4.i2.323
}

\begin{abstract}
This research is measure the influence of environmental factors and individual factors on employee performance on PT.Pos Indonesia (Persero) Office Area II Padang. This study aims to determine the influence of environmental factors, organizational factors and individual factors on employee performance on PT.Pos Indonesia (Persero) Office Area II Padang. This research is a descriptive study associative. The population in this study were all employees of PT. Pos Indonesia (Persero) Office Area II Padang. The sampling technique used is total sampling. The analytical tool used is a validity test, reliability test, normality test, multicolinearity test, multiple linear regression, t-test, $f$, and test the coefficient of determination (R2). Results from this study are: a significant difference between the individual factors on employee performance on PT.Pos Indonesia (Persero) Office Area II Padang. And the influence of environment on employee performance on PT.Pos Indonesia (Persero) Office Area II Padang
\end{abstract}

\begin{abstract}
Abstrak
Penelitian ini bertujuan untuk mengukur pengaruh faktor lingkungan dan faktor individu terhadap kinerja karyawan di PT.Pos Indonesia (Persero) Kantor Wilayah II Padang. Penelitian ini bertujuan untuk mengetahui pengaruh faktor lingkungan, faktor organisasi dan faktor individu terhadap kinerja karyawan di PT.Pos Indonesia (Persero) Kantor Wilayah II Padang. Penelitian ini merupakan penelitian deskriptif asosiatif. Populasi dalam penelitian ini adalah seluruh karyawan PT. Pos Indonesia (Persero) Kantor Wilayah II Padang. Teknik sampling yang digunakan adalah total sampling. Alat analisis yang digunakan adalah uji validitas, uji reliabilitas, uji normalitas, uji multikolinearitas, regresi linier berganda, uji $t$, $f$, dan uji koefisien determinasi (R2). Hasil dari penelitian ini adalah: perbedaan yang signifikan antara faktor individu terhadap kinerja karyawan di PT.Pos Indonesia (Persero) Kantor Wilayah II Padang. Dan pengaruh lingkungan terhadap kinerja karyawan di PT.Pos Indonesia (Persero) Kantor Wilayah II Padang
\end{abstract}

Keyword s: Work Environment Individual Factors And Achievement Employees

C2016 Prodi Pendidikan Ekonomi STKIP PGRI, Padang 


\section{PENDAHULUAN}

Persaingan di dunia kerja yang semakin kompetitif mengakibatkan para pelaku bisnis semakin dituntut untuk memenangkan persaingan sehingga usahanya dapat terus bertahan dan berlanjut di masa mendatang. Hal ini menyebabkan para pelaku bisnis memiliki beban yang besar untuk terus berusaha agar perusahaannya dapat terus bertahan. Untuk itu para pelaku bisnis juga harus mempunyai suatu target guna mempertahankan atau meningkatkan produktivitas dan efektifitas karyawannya. Hal ini membuat kualitas dan kuantitas kerja karyawan ikut meningkat.

Menurut Hasibuan (2009:94) prestasi kerja adalah suatu hasil kerja yang dicapai seseorang dalam melaksanakan tugas-tugas dibebankan kepadanya yang didasarkan kecakapan, pengalaman, kesungguhan serta waktu. Prestasi kerja merupakan outcome atau hasil dari kerja yang dicapai karyawan selama mereka bekerja di perusahaan. Apabila karyawan berkeinginan berprestasi tinggi, ditunjang dengan kecakapan, keterampilan, kemampuan serta moral kerja dan disiplin yang tinggi, maka akan sangat mendukung terwujudnya kinerja yang baik pada perusahaan tersebut.

Untuk menciptakan prestasi kerja yang maksimal, perusahaan tidak hanya harus bisa memilih orang yang tepat tetapi juga perlu ditunjang dengan penciptaan kondisi yang memungkinkan bagi karyawan untuk bekerja optimal, karena dengan kondisi kerja yang baik juga merupakan salah satu faktor pendukung bagi karyawan untuk berkinerja dengan baik.Menurut Robbins (2003:376) pengertian stres adalah suatu kondisi dinamik yang di dalamnya seorang individu dengan apa yang sangat diinginkannya dan yang hasilnya dipersepsikan sebagai tidak pasti dan penting". Robbin juga menjelaskan bahwa stres tidak selalu berdampak buruk. Walaupun stres sering disebut dalam konteks negatif, stres juga memiliki nilainilai positif, tentunya pada stres tersebut menawarkan satu perolehan yang memiliki potensi.

Stres juga dapat muncul saat karyawan mempunyai beban kerja yang terlalau banyak yang tidak dimengerti, tidak adanya dukungan sosial baik keluarga maupun lingkungan perusahaan, manajemen tidak sehat, konflik pekerjaan, dan perubahan tipe pekerjaan yang tidak sesuai dengan kemampuan karyawan adalah merupakan sebagian dari contoh pemicu terjadinya stres.

Oleh karena itu, karyawan harus mampu merespon dan mengelola stres kerja sehingga dapat meningkatkan prestasi kerja dan semangat kerja. Menurut Higgins (dalam Umar, 2005:35,264-266) semakin tinggi stres karena tantangan kerja maka akan mengakibatkan prestasi kerja juga bertambah, tetapi jika stres kerja sudah maksimal maka hal tersebut tidak akan dapat meningkatkan prestasi kerja, tetapi malah akan menurunkan prestasi kerja karyawan.

PT. Pos Indonesia (Persero) Kantor Area II Padang merupakan salah satu perusahaan yang bergerak dalam bidang jasa yang beralamat di jalan Khatib Sulaiman Padang. Karyawan merupakan aset yang penting bagi PT. Pos Indonesia (Persero) Kantor Area II Padang, maka dari itu karyawan diharapkan dapat memberikan dan melakukan yang terbaik agar dapat memberikan hasil yang terbaik bagi PT. Pos Indonesia (Persero) Kantor Area II Padang itu sendiri.

Target yang dimiliki oleh PT.Pos Indonesia (Persero) Kantor Area II Padang adalah untuk memenuhi kebutuhan karyawan di UPT (Unit Pelayanan Teknis), dijelaskan sebagai berikut : 
Tabel 1.Kebutuhan UPT pada tahun 2013

\begin{tabular}{lcccc}
\hline Keterangan & Solok & Dumai & Bukittinggi & Pekanbaru \\
\hline Timah blumbir & $240 \mathrm{~kg}$ & $240 \mathrm{~kg}$ & $360 \mathrm{~kg}$ & $480 \mathrm{~kg}$ \\
Tali jalin & $90 \mathrm{~kg}$ & $90 \mathrm{~kg}$ & $120 \mathrm{~kg}$ & $180 \mathrm{~kg}$ \\
Kantong bungkus & $60 \mathrm{~kg}$ & $60 \mathrm{~kg}$ & $96 \mathrm{~kg}$ & $120 \mathrm{~kg}$ \\
ulang & & & & \\
Libel alamat & 1800 helai & $1800 \mathrm{helai}$ & $2400 \mathrm{helai}$ & $3600 \mathrm{buah}$ \\
$\begin{array}{l}\text { Resi } \\
\text { Komputer dan }\end{array}$ & $24 \mathrm{kotak}$ & 24 kotak & $36 \mathrm{kotak}$ & $60 \mathrm{kotak}$ \\
perlengkapan & 2 unit & 2 unit & 3 unit & 5 unit \\
\hline
\end{tabular}

Sumber : Data Sekunder 2013

Berdasarkan uraian di atas, penulis merasa tertarik untuk membahas hal ini menjadi sebuah penelitian yang berjudul: "Pengaruh Faktor lingkungan kerja dan Faktor Individu Terhadap Prestasi Kerja Karyawan Pada PT. Pos Indonesia (Persero) Kantor Area II Padang"

Dari uraian latar belakang masalah di atas, maka penulis merumuskan masalah yang akan diteliti dalam penelitian yaitu :

1. Sejauhmana pengaruh faktor lingkungan terhadap prestasi kerja karyawan pada PT. Pos Indonesia (Persero) Kantor Area II Padang

2. Sejauhmana pengaruh faktor organisasi terhadap prestasi kerja karyawan pada PT. Pos Indonesia (Persero) Kantor Area II Padang

3. Sejauhmana pengaruh faktor individu terhadap prestasi kerja karyawan pada PT. Pos Indonesia (Persero) Kantor Area II Padang

Adapun tujuan dari penelitian ini adalah :

1. Untuk mengetahui pengaruh faktor lingkungan terhadap prestasi kerja karyawan pada PT. Pos Indonesia (Persero) Kantor Area II Padang

2. Untuk mengetahui pengaruh faktor organsasi terhadap prestasi kerja karyawan pada PT. Pos Indonesia (Persero) Kantor Area II Padang

3. Untuk mengetahui pengaruh stres kerja terhadap prestasi kerja karyawan pada PT. Pos Indonesia (Persero) Kantor Area II Padang

\section{Prestasi Kerja}

Menurut Hasibuan

(2009:94)

menyatakan bahwa Prestasi kerja adalah sesuatu hasil kerja yang dicapai seseorang dalam melaksanakan tugas-tugas dibebankan kepadanya yang didasarkan kecakapan, pengalaman dan kesungguhan serta waktu. Prestasi kerja merupakan gabungan dari tiga faktor penting, yaitu kemampuan dan minat seorang pekerja, kemampuan dan penerimaan atas penjelasan delegasi tugas, serta peran dan tingkat motivasi seorang pekerja. Semakin tinggi ketiga faktor diatas, semakin besarlah prestasi kerja karyawan yang bersangkutan.

Sedangkan Prestasi kerja menurut Hersey dan Blanchard (dalam Rivai,2005:15) merupakan suatu fungsi dari motivasi dan kemampuan, untuk menyelesaikan tugas atau pekerjaan. Seseorang harus memiliki tingkat kemampuan tertentu. Keterampilan seseorang tidaklah cukup efektif untuk mengerjakan sesuatu tanpa pemahaman yang jelas tentang apa yang akan dikerjakan dan bagaimana mengerjakannya.

Dari beberapa pendapat di atas dapat disimpulkan bahwa prestasi kerja adalah hasil kerja yang dicapai seseorang menurut standar yang ditetapkan oleh perusahaan dalam suatu periode.

\section{Stres Kerja}

Menurut Anoraga (2009:108) mengatakan stres kerja merupakan suatu bentuk tanggapan seseorang baik secara 
fisik maupun mental, terhadap suatu perubahan di lingkungannya yang dirasakan mengganggu dan mengakibatkan dirinya terancam. Sedangkan menurut Robbins (2001:563) mengatakan stres sebagai kondisi yang menekan keadaan psikis seseorang dalam mencapai kesempatan tersebut terdapat batasan atau penghalang.

Gibson (dalam Rivai, 2011:307) mengemungkakan bahwa stres kerja dikonseptualisasi dari beberapa titik pandang, yaitu stres sebagai stimulus, stres sebagai respon dan stres sebagai stimulusrespon. Stres sebagai stimulus merupakan pendekatan yang menitik beratkan pada lingkungan. Defenisi stimilus memandang stres sebagai sesuatu kekuatan yang menekan individu untuk memberikan tanggapan terhadap stresor. Pendekanan ini memandang stres sebagai konsekuensi dari interaksi.

Dari definisi di atas dapat disimpulkan bahwa stres adalah sebagai suatu keadaan yang mempengaruhi emosi, kondisi fisik dan mental seseorang pada saat ia dihadapkan dengan kesempatan, keterbatasan, dan tuntutan yang dihubungkan dengan apa yang diinginkannya yang hasilnya ditujukan pada sebagai suatu yang tidak pasti.

\section{Faktor-faktor Penyebab Stres}

Menurut Robbin (2003:794-798) penyebab stres itu ada 3 faktor yaitu:

1. Faktor Lingkungan

Ada beberapa faktor yang mendukung faktor lingkungan, yaitu:

a. Perubahan situasi bisnis yang menciptakan ketidakpastian ekonomi. Bila perekonomian itu menjadi menurun, orang menjadi semakin mencemaskan kesejahteraan mereka.

b. Ketidakpastian politik. Situasi politik yang tidak menentu seperti yang terjadi di Indonesia, banyak sekali demonstrasi dari berbagai kalangan yang tidak puas dengan keadaan mereka. Kejadian semacam ini dapat membuat orang merasa tidak nyaman. Seperti penutupan jalan karena ada yang berdemo atau mogoknya angkutan umum dan membuat para karyawan terlambat masuk kerja.

c. Kemajuan teknologi. Dengan kemajuan teknologi yang pesat, maka hotel pun menambah peralatan baru atau membuat sistem baru. Yang membuat karyawan harus mempelajari dari awal dan menyesuaikan diri dengan itu.

d. Terorisme adalah sumber stres yang disebabkan lingkungan yang semakin meningkat dalam abad ke 21, seperti dalam peristiwa penabrakan gedung WTC oleh para teroris, menyebabkan orangorang Amerika merasa terancam keamanannya dan merasa stres.

2. Faktor Organisasi

Banyak sekali faktor di dalam organisasi yang dapat menimbulkan stres. Tekanan untuk menghindari kekeliruan atau menyelesaikan tugas dalam kurun waktu terbatas, beban kerja berlebihan, bos yang menuntut dan tidak peka, serta rekan kerja yang tidak menyenangkan dapat dijelaskan sebagai berikut :

a. Tuntutan tugas merupakan faktor yang terkait dengan tuntutan atau tekanan untuk menunaikan tugasnya secara baik dan benar.

b. Tuntutan peran berhubungan dengan tekanan yang diberikan pada seseorang sebagai fungsi dari peran tertentu yang dimainkan dalam organisasi itu. Konflik peran menciptakan harapan-harapan yang barangkali sulit dirujukkan atau dipuaskan. Kelebihan peran terjadi bila karyawan diharapkan untuk melakukan lebih daripada yang dimungkinkan oleh waktu. Ambiguitas peran tercipta bila harapan peran tidak dipahami dengan jelas dan karyawan tidak pasti mengenai apa yang harus dikerjakan.

c. Tuntutan antar pribadi adalah tekanan yang diciptakan oleh karyawan lain. 
Kurangnya dukungan sosial dari rekanrekan dan hubungan antar pribadi yang buruk dapat menimbulkan stres yang cukup besar, khususnya diantara para karyawan yang memiliki kebutuhan sosial yang tinggi.

d. Struktur Organisasi menentukan tingkat diferensiasi dalam organisasi, tingkat aturan dan peraturan dan dimana keputusan itu diambil. Aturan yang berlebihan dan kurangnya berpartisipasi dalam pengambilan keputusan yang berdampak pada karyawan merupakan potensi sumber stres.

3. Faktor Individu

Faktor ini mencakup kehidupan pribadi karyawan terutama faktor-faktor persoalan keluarga, masalah ekonomi pribadi dan karakteristik kepribadian bawaan.

a. Faktor persoalan keluarga.

Survei nasional secara konsistenmenunjukkan bahwa orang menganggap bahwa hubungan pribadi dankeluarga sebagai sesuatu yang sangat berharga.

Kesulitan pernikahan,pecahnya hubungan dan kesulitan disiplin anak-anak merupakancontoh masalah hubungan yang menciptakan stres bagi karyawan danterbawa ke tempat kerja.

b. Masalah Ekonomi.

Diciptakan oleh individu yang tidak dapatmengelola sumber daya keuangan mereka merupakan satu contohkesulitan pribadi yang dapat menciptakan stres bagi karyawan danmengalihkan perhatian mereka dalam bekerja.

c. Karakteristik kepribadian bawaan.

Faktor individu yang penting mempengaruhi stres adalah kodrat kecenderungan dasar seseorang. Artinya gejala stres yang diungkapkan pada pekerjaan itu sebenarnya berasal dari dalam kepribadian orang itu.

\section{Kerangka Konseptual}

Diantara hubungan factor lingkungan dan factor individu dengan prestasi kerja, dapat digambarkan dalam kerangka konseptual sebagai berikut :

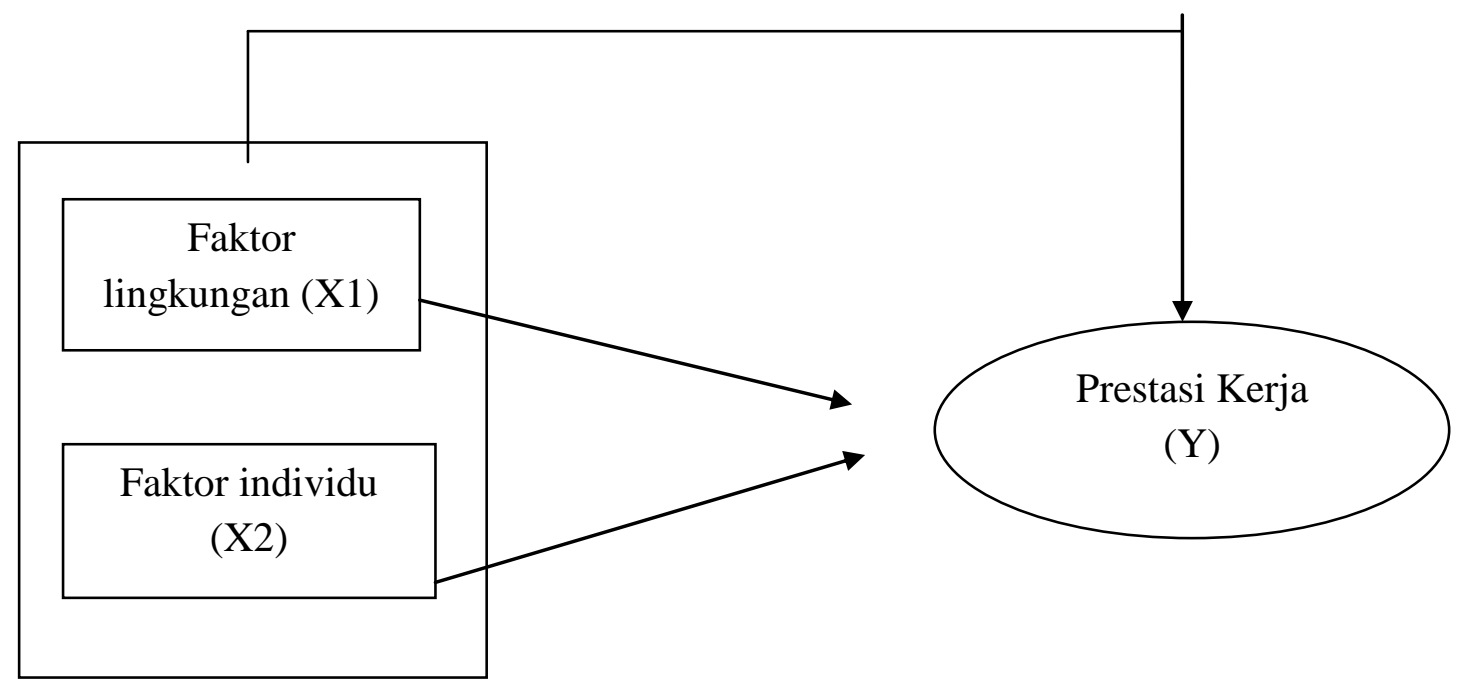

\section{Gambar 1. Kerangka Konseptual}

Berdasarkan gambar 1. dapat dijelaskan bahwa variabel faktor lingkungan seperti kondisi fisik, manajemen kantor, hubungan sosial.. Faktor individu seperti faktor keluarga, masalah ekonomi, serta karakteristik kepribadian atau bawaan) mempengaruhi prestasi kerja karyawan.

\section{METODE PENELITIAN}


Jenis penelitian yang digunakan adalah deskriptif asosiatif. Siregar (2013:15) menyatakan bahwa penelitian deskriptif asosiatif adalah penelitian yang betujuan untuk mengetahui hubungan sebab-akibat antara dua variabel atau lebih.
Populasi dalam penelitian ini adalah Karyawan PT. Pos Indonesia (Persero) Kantor Area II Padang pada Tahun 2013 yang berjumlah 60 orang. Untuk lebih jelasnya yang menjadi populasi dalam penelitian ini dapat dilihat dari Tabel sebagai berikut:

Tabel . 3 Populasi Penelitian

\begin{tabular}{clc}
\hline No. & \multicolumn{1}{c}{ Area } & Populasi \\
\hline 1. & Bagian Penjualan & 7 \\
2. & Bagian Teknologi Informasi & 4 \\
3. & Bagian Operasi & 10 \\
4. & Bagian Akuntansi & 2 \\
5. & Bagian Jasa Keuangan & 8 \\
6. & Bagian SDM & 22 \\
7. & Perwakilan SPI Jumlah & 7 \\
\hline & & 60
\end{tabular}

Sumber: Bagian Administrasi PT. Pos Indonesia (Persero) Kantor Area II Padang tahun 2015

Dalam penelitian ini di gunakan sistem penentuan sampelnya yaitu total sampling karena populasinya kurang dari 100 orang karyawan. Jadi, jumlah sampel adalah 60 orang karyawan PT.Pos Indonesia (Persero) Kantor Area II Padang.

Adapun variabel yang dipakai dalam penelitian ini adalah ; Variabel independen atau variabel bebas yaitu 1) Faktor lingkungan, yang dilambangkan dengan X1 (ketidakpastian ekonomi, ketidak pastian politik, kemajuan teknologi dan terorisme). 2) Faktor Individu yang dilambangkan dengan X2 (faktor persoalan keluarga, masalah ekonomi, karakteristik kepribadian bawaan). Sedangkan variable dependent atau variable terikat yaitu Prestasi kerja, yang dilambangkan dengan Yadalah: sebagai kecakapan seseorang pada tugastugas yang mencakup pada pekerjaannya untuk mencapai hasil kerja secara kualitas dan kuantitas yang dicapai oleh seseorang pegawai dalam melaksanakan tugasnya sesuai dengan tanggung jawab yang diberikan kepadanya.

Analisis data yang digunakan dalam penelitian ini adalah analisis regersi linear berganda dengan persamaan sebagai berikut

$$
\begin{array}{ll}
\mathrm{Y}=\mathrm{a}+\mathrm{b}_{1} \mathrm{X}_{1}+\mathrm{b}_{2} \mathrm{X}_{2}+e \\
\text { dimana: } \\
\mathrm{Y} & : \text { Prestasi Kerja Karyawan } \\
\mathrm{a} & : \text { Konstanta } \\
\mathrm{X}_{1} & : \text { Faktor Lingkungan kerja } \\
\mathrm{X}_{2} & : \text { Faktor Individu } \\
\mathrm{b}_{1} & : \text { Koefisien regresi variabel } \\
\mathrm{X}_{1} & \\
\mathrm{~b}_{2} & : \text { Koefisien regresi variabel } \\
\mathrm{X}_{2} & \\
\varepsilon & : \text { Error (kesalahan) }
\end{array}
$$

\section{PEMBAHASAN}

Dari hasil pengujian hipotesisi diketahui secara parsial faktor lingkungan berpengaruh signifikan positif terhadap prestasi kerja karyawan PT. Pos Indonesia (Persero) Kantor Area II Padang. Hal ini dapat dibuktikan dengan hasil penelitian yang menyatakan bahwa $t_{\text {hitung }}(5,330)>$ 
$t_{\text {Tabel }}(1,671)$ dan sig $(0,000)<\alpha(0,05)$ artinya $\mathrm{H}_{\mathrm{o} 1}$ ditolak $\mathrm{H}_{\mathrm{a} 1}$ diterima. Dari nilai koefesien regresi faktor lingkungan $\left(b_{1}\right)$ sebesar 1,027 dapat diartikan, apabila karyawan PT. Pos Indonesia (Persero) Kantor Area II Padang memiliki tingkat stress kerja dari factor lingkungan naik sebesar satu satuan maka Prestasi Kerja karyawan hanya meningkat sebesar 1,027 satuan

Faktor lingkungan kerja dapat berupa kondisi fisik, manajemen kantor maupun hubungan sosial dilingkungan pekerjaan Hal ini senada dengan pendapat Higgins (dalam Umar, 2005:35,264-266), bahwa ada korelasi langsung antara stres dengan prestasi kerja. Stres yang dialami karyawan bisa berdampak negatif dan positif bagi prestasi kerja tergantung dari sudut pandang mana seseorang atau karyawan dapat mengatasi tiap kondisi yang menekannya untuk dapat dijadikan acuan sebagai tantangan kerja yang akan memberikan hasil yang baik atau sebaliknya. Bila stres menjadi begitu besar, prestasi kerja akan mulai menurun, karena stres mengganggu pelaksanaan pekerjaan (menurut Newstrom, 1993:201).

Dari hasil pengujian hipotesisi diketahui secara parsial faktor individu berpengaruh signifikan positif terhadap prestasi kerja karyawan PT. Pos Indonesia (Persero) Kantor Area II Padang. Hal ini dapat dibuktikan dengan hasil penelitian yang menyatakan bahwa $t_{\text {hitung }}(4,584)>$ $\mathrm{t}_{\text {Tabel }}(1,671)$ dan sig $(0,000)<\alpha(0,05)$ artinya $\mathrm{H}_{\mathrm{o} 3}$ ditolak $\mathrm{H}_{\mathrm{a} 3}$ diterima. Dari koefesien regresi faktor individu $\left(b_{3}\right)$ sebesar 1,087 dapat berarti, apabila karyawan PT. Pos Indonesia (Persero) Kantor Area II Padang memiliki tingkat stress kerja dari faktor individu naik sebesar satu satuan maka Prestasi Kerja karyawan hanya meningkat sebesar 1,087 satuan.

Banyak sekali faktor di dalam individu yang dapat menimbulkan stres. Faktor ini mencakup kehidupan pribadi karyawan terutama faktor-faktor persoalan keluarga, masalah ekonomi pribadi dan karakteristik kepribadian bawaan. Hal ini senada dengan pendapat Higgins (dalam Umar, 2005:35,264-266), bahwa ada korelasi langsung antara stres dengan prestasi kerja. Stres yang dialami karyawan bisa berdampak negatif dan positif bagi prestasi kerja tergantung dari sudut pandang mana seseorang atau karyawan dapat mengatasi tiap kondisi yang menekannya untuk dapat dijadikan acuan sebagai tantangan kerja yang akan memberikan hasil yang baik atau sebaliknya. Bila stres menjadi begitu besar, prestasi kerja akan mulai menurun, karena stres mengganggu pelaksanaan pekerjaan (menurut Newstrom, 1993:201).

\section{DAFTAR PUSTAKA}

10.22202/economica.2016.v4.i2.323

Anoraga, Pandji. 2009. Psikologi Kepemimpinan, Cetakan Ketiga, Rineka Cipta, Jakarta.

Hasibuan H, Malayu. 2009. “Organisasi dan motivasi”. PT. Bumi Aksara. Jakarta.

Robbins, Stephen. P. 2003. Organizational Behavior. PT Indeks Kelompok Gramedia. Jakarta.

Umar, Husein. 2005. "Riset Sumber Daya Manusia dalam Organisasi”. PT. Gramedia Pustaka Utama. Jakarta.

Veithzal Rivai. 2004. Manajemen Sumber Daya Manusia Untuk Perusahaan : Dari Teori Ke Praktik. PT. Raja Grafindo Persada, Jakarta. 